\title{
Analisis Komposisi dan Kandungan Karotenoid Total dan Vitamin A Fraksi Cair dan Padat Minyak Sawit Kasar (CPO) Menggunakan KCKT Detektor PDA
}

\author{
M. Rio Syahputra ${ }^{1,2)}$, Ferry F. Karwur ${ }^{1)}$ dan Leenawaty Limantara ${ }^{1,3)}$ \\ 1) Universitas Kristen Satya Wacana, Jawa Tengah, 50711 \\ 2) Research Institute of PT SMART Tbk, Siak, Riau \\ 3) Ma Chung Research Center, Universitas Ma Chung, Malang 65151
}

Diterima 20-05-2007 Disetujui 29-01-2008

\begin{abstract}
This study was carried out on two phases of Crude Palm Oil (CPO) to determine the total and composition of carotenoid and vitamin A content. Total of carotenoid was analyzed using spectrophotometer UV-Vis, and then the result was calculated by Gross (1991) equation. The vitamin A content was calculated by NAS-NRC equation (1974). The type and composition of both phases of CPO were determined by Choo's method (1994) by using HPLC with Photo Diode Array (PDA) detector. The sample was prepared in two methods, with and without saponification. The result shows that total carotenoids in liquid and solid phase of CPO are $536 \pm 13.2 \mu \mathrm{g} / \mathrm{g}$ (liquid), $352 \pm 17.7 \mu \mathrm{g} / \mathrm{g}$ (solid) and the vitamin A were 89.4 $\pm 2.2 \mathrm{RE}$ (liquid), 58.7 $\pm 3.0 \mathrm{RE}$ (solid), respectively. The carotenoid compositions of both phases of CPO were dominated by $\alpha$ - and $\beta$-carotenes. The result shows that $\alpha$ - and $\beta$-carotenes prepared by saponification method in liquid phase are $29.03 \%$ and $60.88 \%$, and without saponification (direct method) are $28.14 \%$ and $59.44 \%$. The result for solid phase shows that $\alpha$ - and $\beta$-carotenes by saponification are $25.89 \%$ and $60.81 \%$, and without saponification (direct method) are $30.00 \%$ and $56.92 \%$. The research also shows the advantages of using HPLC with PDA detector for identification and analysis of type and carotenoid composition.
\end{abstract}

Keywords: carotenoid, Crude Palm Oil (CPO), vitamin A

\section{PENDAHULUAN}

Kelapa sawit (Elaeis) termasuk golongan tumbuhan palma (Arecaceae). Tanaman ini terdapat dalam tiga spesies, E. guineensis, E. Oleifera dan E. Odora. Spesies pertama dan kedua berasal dari Afrika dan Amerika, sedangkan spesies ketiga tidak dikultivasi sehingga sangat sedikit informasi tentang spesies tersebut (Henderson 1986).

Minyak sawit yang menjadi hasil utama dari kelapa sawit telah diperdagangkan ke luar Afrika akhir abad ke-18, namun masih dalam jumlah kecil. Pada tahun 1790, kurang dari 130 ton minyak sawit diekspor ke Inggris. Perdagangan minyak sawit terus meningkat, tercatat pada tahun 1830 lebih kurang 12.000 ton minyak sawit dikirim ke Inggris. Peningkatan perdagangan komoditi ini dipicu oleh peningkatan permintaan minyak nabati untuk industri sabun dan bahan pangan (Corley 2003).

Kelapa sawit masuk ke Indonesia pada tahun 1848 sebagai tanaman hias di Kebun Raya Bogor, dan tanaman secara massal di Sumatera pada tahun 1911. Ekspor minyak sawit pertama dilakukan pada tahun 1919 (Corley 2003). Perkebunan kelapa sawit saat ini tersebar hampir di seluruh wilayah Indonesia dan berkembang seiring peningkatan permintaan akan komoditas ini. Indonesia dan Malaysia merupakan negara pengekspor kelapa sawit terbesar dunia. Berdasarkan data Oil World 2006, Indonesia memberikan kontribusi lebih kurang 41,5\% minyak sawit dunia, sedikit di bawah Malaysia, 44,5\% (Anonim 2006).

Bagian yang paling populer untuk diolah dari kelapa sawit adalah buahnya. Buah diproses dengan melunakkan daging buah pada temperatur $90^{\circ} \mathrm{C}$. Daging yang telah lunak dipisahkan dari bagian inti dan cangkang dengan dikempa (pressing) pada mesin silinder berlubang sehingga dihasilkan minyak kelapa sawit kasar (CPO). CPO berbentuk lemak semi padat pada temperatur kamar yang terdiri atas 2 fraksi yaitu fraksi cair (olein, 70-80\%) dan fraksi padat (stearin, 2030\%) (Corley 2003; Gunstone 1987; Naibaho 1998).

Pengolahan CPO melewati proses fraksinasi berdasarkan perbedaan titik leleh menghasilkan beberapa fraksi, selanjutnya diolah sesuai dengan produk yang diinginkan. Fraksi cair banyak mengandung trigliserida dengan titik leleh rendah. 
Fraksi cair inilah yang kemudian diolah menjadi bahan baku minyak goreng, dengan keunggulan daya tahan oksidasi yang lebih baik dan stabil pada suhu tinggi. Untuk memberikan cita rasa yang berbeda, olein dicampur dengan bahan lain, misalnya dengan tepung beras (Jepang) dan dengan minyak kacang tanah (Malaysia). Sebaliknya fraksi padat berbentuk padatan yang mengandung trigliserida dengan titik leleh rendah dan nilai iodin yang lebih tinggi. Fraksi padat merupakan sumber utama lemak padat alami yang diolah menjadi lemak padat, mentega, dan lain sebagainya (Corley 2003).

Minyak sawit sebagian besar terdiri atas gliseridagliserida yang tersusun dari beberapa asam lemak. Trigliserida-trigliserida sebagai komponen utama, dengan sedikit digliserida dan monogliserida. Selain itu, minyak sawit juga mengandung komponenkomponen minor seperti karotenoid, vitamin $\mathrm{E}$ (tokoferol dan tokotrienol), sterol, fosfolipid, glikolipid, terpenoid dan hidrokarbon alifatik. Dari komponen-komponen tersebut, vitamin $\mathrm{E}$ dan karotenoid memiliki potensi yang penting (Choo 1994; Corley 2003; Paiva 1999).

Minyak sawit kasar atau CPO merupakan salah satu sumber karoten tertinggi yang diekuivalenkan dengan retinol (pro-vitamin A). Kandungan karoten berbeda menurut varietas dan kematangan buah. Kandungan karotenoid CPO dari varietas Tenera berkisar antara 500-700 ppm, sedangkan varietas Dura yang berasal dari Nigeria berkisar antara 800-1600 ppm. Ditinjau dari struktur molekul, karotenoid minyak sawit terdiri atas beberapa senyawa karoten, dengan kandungan utama $\alpha$ - dan $\beta$-karoten (Choo 1994; Paiva 1999; Naibaho 1998; Corley 2003). Kandungan karotenoid menjadi sangat diperhatikan setelah adanya persyaratan minimum kadar total karoten sebesar 500 $\mathrm{mg} / \mathrm{kg}$ CPO dari negara-negara importir seperti India, Belanda, Spanyol dan negara-negara Eropa (Pangaribuan \& Asnawi 2005).

Salah satu fungsi penting karotenoid adalah sebagai prekursor vitamin A yang akan diubah oleh tubuh menjadi vitamin A (Lee dkk. 1989; Groos 1991; Sharma dkk. 2000; Lila 2004). Karotenoid provitamin A yang potensial dan banyak terdapat di alam adalah $\beta$ karoten (Gross 1991; Bonnie \& Choo 2000; Nyambaka \& Riley 1996). Seperti kita ketahui, vitamin A sangat berguna dalam membantu proses penglihatan, pertumbuhan tulang dan gigi, reproduksi, pertahanan keutuhan jaringan epitel, kekebalan tubuh, pembentukan dan pemeliharaan sel-sel kulit, saluran pencernaan dan selaput kulit, serta dapat mencegah timbulnya penyakit kanker (Choo 1994).

Pada bidang kesehatan, karotenoid terutama $\beta$ karoten merupakan salah satu senyawa antioksidan alami. Antioksidan berfungsi sebagai pemadam (quencher) oksigen singlet dan penangkal radikal bebas, yang berlangsung dalam sistem fotosintesis tumbuhan, tetapi juga dalam tubuh manusia maupun hewan. Oksigen singlet adalah molekul oksigen yang sangat reaktif, dapat menginisiasi peroksida lipid hingga terjadi reaksi berantai radikal bebas yang dapat mengoksidasi komponen sel lain, seperti protein dan DNA, yang dapat memicu penuaan dini pada manusia. Sejumlah penelitian menunjukkan bahwa oksigen singlet yang berbahaya ini dapat dinonaktifkan oleh $\beta$ karoten. Selain itu, $\beta$-karoten juga mampu bereaksi dengan radikal bebas $(R)$ dengan proses transfer muatan (elektron). Pada reaksi ini akan diperoleh radikal bebas $\beta$-karoten yang relatif lebih stabil dan tidak memiliki energi yang cukup untuk dapat bereaksi dengan molekul lain membentuk radikal baru (Britton 1995; Gordon 1990; Gross 1991)

$\beta$-karoten di alam umumnya terdapat dalam bentuk trans, tetapi dapat terisomerisasi karena pengaruh lingkungan seperti suhu dan cahaya ke bentuk cis- $\beta$ karoten. Lebih lanjut $\beta$-karoten, yang terisomerisasi mudah mengalami degradasi oleh keberadaan oksigen (Bonnie \& Choo 1999; Gross 1991).

Melihat sifat karotenoid yang relatif kurang stabil, sangat memungkinkan terjadinya degradasi $\beta$-karoten selama proses pengolahan CPO, terutama pada tahap ekstraksi, penyimpanan dan transportasi. Hal ini diakibatkan oleh pemanasan berlebihan, kehadiran oksigen dan kontak dengan logam (besi, krom, dll.) yang menginisiasi oksidasi sehingga komposisi dan aktivitas antioksidan karotenoidnya menurun (Gunstone 1987).

Berdasarkan latar belakang di atas, maka tujuan penelitian ini adalah menentukan kandungan total dan komposisi karotenoid pada fraksi cair dan padat CPO dengan metoda saponifikasi dan metoda langsung.

KCKT dengan detektor PDA. Perkembangan KCKT merupakan suatu terobosan untuk analisis karotenoid, salah satunya adalah paduan dengan detektor PDA. Pada KCKT dengan detektor UV-tampak 
konvensional pengukuran hanya dapat dilakukan pada satu panjang gelombang, sehingga untuk menentukan komposisi suatu sampel pada banyak panjang gelombang harus dilakukan pengukuran berulang-ulang. Hal ini berbeda dengan KCKT detektor PDA, pengukuran dapat dilakukan pada banyak panjang gelombang secara simultan, sehingga dapat diperoleh komposisi suatu sampel pada rentang panjang gelombang yang diinginkan. Keunggulan lain, rentang panjang gelombang dapat menghasilkan pola spektra dari puncak-puncak yang diperoleh sehingga secara kualitatif dapat ditentukan tanpa harus menganalisis marker (Briton 1995; Choo 1994).

\section{BAHAN DAN METODE}

Sampel yang digunakan adalah minyak sawit kasar (CPO) yang diperoleh dari salah satu pabrik pengolahan CPO PT. Sinar Mas Agro Research and Technology, Tbk (PT. SMART Tbk), yang berlokasi di Kabupaten Siak, Riau. Bahan yang digunakan adalah aseton, etanol, petroleum eter, dietileter, heksan, $\mathrm{KOH}$, asam askorbat, metanol, marker $\beta$-karoten (E-Merck No. Kat. 1.02236), asetonitril, diklorometan, isopropanol.

Persiapan Fraksi Cair dan Padat CPO. Sampel CPO pada suhu ruang disaring menggunakan kertas saring whatman 42 dengan bantuan pompa vakum sehingga fraksi padat (stearin) dan fraksi cair (olein) terpisah.

Penentuan Kadar Karotenoid Kasar (Gross 1987; 1991) $0,1 \mathrm{~g} \mathrm{CPO} \mathrm{(fraksi} \mathrm{padat/cair)} \mathrm{dilarutkan} \mathrm{dalam}$ pelarut heksan dalam labu ukur $25 \mathrm{ml}$ hingga tanda batas. Selanjutnya diukur menggunakan Spektrofotometer Varian Carry pada panjang gelombang $470 \mathrm{~nm}$.

Konversi Karotenoid-Vitamin A (Gross 1987; 1991). Berdasarkan hasil pengukuran absorbansi yang diperoleh, jumlah karotenoid dalam mikrogram per gram sampel olein dan stearin dapat dihitung dengan persamaan Gross (Gross 1991). Kandungan total vitamin A dihitung dengan mengkonversi total karotenoid dengan rumusan NAS-NRC (NAS-NRC, 1974), di mana $1 \mathrm{IU}$ (International Unit) setara dengan 0,3 $\mathrm{mg}$ retinol (Gross 1987).

Ekstraksi dan Saponifikasi (AOAC 1984). $1 \mathrm{~g}$ CPO (fraksi padat/cair) dimasukkan ke dalam erlenmeyer $250 \mathrm{ml}$ dan ditambahkan $1 \mathrm{~g}$ askorbat serta $25 \mathrm{ml}$ akuades. Larutan kemudian diaduk menggunakan pengaduk magnet sampai semua askorbat larut. Setelah itu $50 \mathrm{ml}$ etanol dan $10 \mathrm{ml}$ larutan $\mathrm{KOH} \mathrm{60 \%}$ ditambahkan dan diaduk selama satu jam. Ke dalam campuran tersebut ditambahkan $60 \mathrm{ml}$ petroleum eter : dietil eter $(1: 1, \mathrm{v} / \mathrm{v})$ dan diaduk kembali selama satu jam dan kemudian dimasukkan ke dalam corong pisah $500 \mathrm{ml}$

Campuran dikocok dan kemudian dibiarkan sampai terbentuk dua lapisan yang terpisah sempurna. Lapisan bagian atas (larutan 1) dipindahkan ke dalam corong pisah lain, sedangkan lapisan bawah kembali ditambahkan $25 \mathrm{ml}$ petroleum eter dan dietil eter $(1: 1, v / v)$, kemudian diaduk kembali menggunakan pengaduk magnet selama 30 menit. Campuran yang terbentuk dimasukkan ke dalam corong pisah, dikocok dan kemudian dibiarkan hingga terbentuk dua lapisan yang terpisah sempurna. Lapisan bagian atas (larutan 2) digabungkan dengan larutan 1. Perlakuan yang sama dilakukan kembali untuk lapisan bawah sehingga diperoleh gabungan larutan 1, 2, dan 3.

Gabungan larutan di atas dicuci dengan air hingga bebas basa. Setelah itu larutan dipindahkan ke dalam labu dasar bulat dan diuapkan dengan menggunakan evaporator vakum hingga kering.

Metode Langsung. Sebanyak 0,1 g CPO (fraksi padat/cair) dilarutkan dalam pelarut heksan dalam labu ukur $25 \mathrm{ml}$ hingga tanda batas. Larutan tersebut selanjutnya dianalisis menggunakan KCKT Shimadzu LC-20A.

Identifikasi Komposisi Karotenoid dengan KCKT (Bonnie \& Choo 2000). Sampel hasil kedua metoda, saponifikasi dan metoda langsung dari masingmasing fraksi CPO disaring menggunakan filter polytetrafluoroethylene (PTFE) 0,20 $\mu \mathrm{m}$. Kemudian Iarutan hasil filtrasi dianalisis menggunakan Kromatografi Cair Kinerja Tinggi (KCKT) Shimadzu LC20AB yang dilengkapi dengan detektor Photodiode Array (PDA) pada panjang gelombang 190-800 nm, dengan sistem gradien menggunakan kolom VP ODS C18 RP (4.6 mm i.d. $\times 250 \mathrm{~mm}, 5 \mu \mathrm{m})$ dan campuran pelarut asetonitril : diklorometan $(89: 11, \mathrm{v} / \mathrm{v})$ dengan laju alir 1,0 ml menit ${ }^{-1}$.

\section{HASIL DAN PEMBAHASAN}

Pola Spektra Karotenoid Fraksi Cair dan

Padat CPO. Spektra CPO baik untuk fraksi cair dan padat diperoleh dengan melarutkan masing-masing 
sampel dalam pelarut heksan. Dari kedua fraksi CPO yang dibandingkan dengan marker $\beta$-karoten, diperoleh pola spektra yang identik baik fraksi cair maupun padat, yang menunjukkan bahwa kedua fraksi CPO mengandung karotenoid (Gambar 1). Spektra yang dihasilkan membentuk pola yang hampir sama dengan marker, dengan sedikit perbedaan yaitu munculnya puncak baru pada panjang gelombang $335 \mathrm{~nm}$ yang merupakan $\beta$-karoten bentuk cis (Gross 1991; Britton 1995).

Kandungan Total Karotenoid Provitamin A. Kandungan karotenoid provitamin A berhubungan erat dengan aktivitas vitamin $A$, sehingga kandungan karotenoid yang ada dalam fraksi padat maupun cair pada CPO dapat dikonversi ke vitamin A (Tabel 1).

Karotenoid tersebut terdistribusi dalam kedua fraksi. Kandungan karotenoid total CPO fraksi cair lebih tinggi daripada fraksi padatnya. Sebenarnya hal ini dapat terlihat dari warna fraksi cair yang lebih merah dibandingkan fraksi padat. Perbedaan kandungan karotenoid tersebut dipengaruhi oleh perbedaan komposisi asam lemak penyusun CPO pada fraksi cair dan padat; fraksi cair lebih banyak mengandung asam lemak tak jenuh, sedangkan fraksi padat banyak mengandung asam lemak jenuh. Jika dibandingkan dengan komoditi lainnya seperti jeruk ( $R E \approx 0,21 \mu \mathrm{g}$ ),

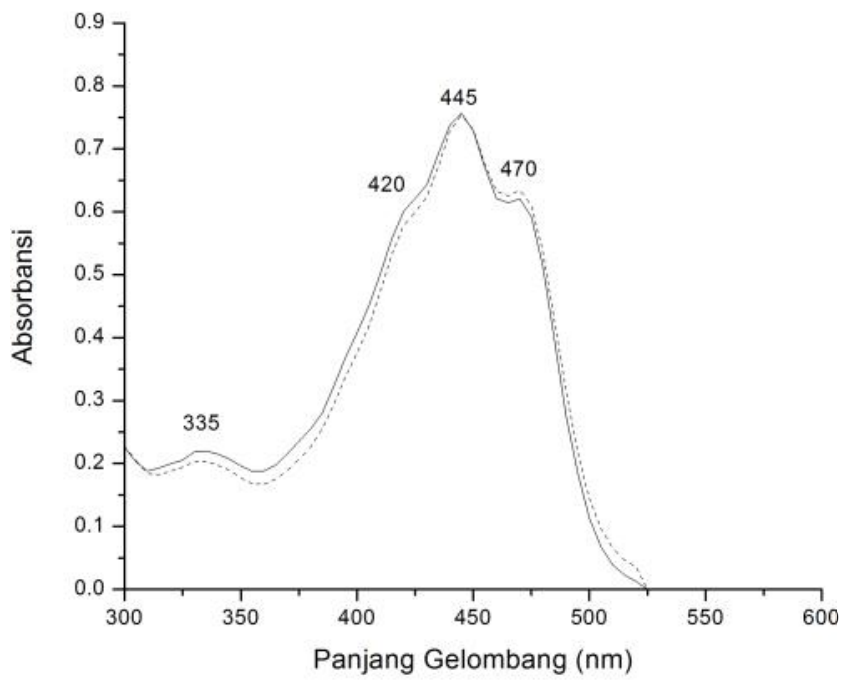

Gambar 1. Pola spektra fraksi cair $(\cdots)$ dan fraksi padat $(\rightarrow$ CPO dalam pelarut heksan

Tabel 1. Kandungan total karotenoid $(\mu \mathrm{g} / \mathrm{g})$ dan konversi vitamin A (RE/IU) fraksi cair dan padat CPO

\begin{tabular}{lccc}
\hline & \begin{tabular}{c} 
Kandungan \\
Karotenoid \\
\cline { 3 - 4 }
\end{tabular} & \multicolumn{2}{c}{ Konversi Vitamin A } \\
\cline { 3 - 4 } & RE \pm SE & IU \pm SE \\
\hline Fraksi Cair & $536 \pm 13,2$ & $89 \pm 2,2$ & $297 \pm 7,3$ \\
Fraksi Padat & $352 \pm 14,2$ & $59 \pm 3,0$ & $196 \pm 1.6$ \\
\hline
\end{tabular}

pisang $(\mathrm{RE} \approx 0,50 \mu \mathrm{g})$ dan wortel $(\mathrm{RE} \approx 4 \mu \mathrm{g})$, CPO (fraksi cair 89,4 $\pm 2,2 \mathrm{RE}$ dan padat 58,7 $\pm 3,0 \mathrm{RE}$ ), terlihat $\mathrm{CPO}$ memiliki kandungan karotenoid dan vitamin A yang jauh lebih tinggi (Anonim 2006). Jumlah kebutuhan vitamin A yang dianjurkan untuk setiap orang adalah 1000 RE/hari (Gross 1991). Kebutuhan tersebut dapat terpenuhi dari $10 \mathrm{~g}$ CPO.

Penentuan Komposisi Karotenoid dengan KCKT. Kromatogram KCKT ekstrak dari kedua fraksi cair dan padat CPO dapat dilihat pada Gambar 2 dan 3. Kromatogram ditampilkan pada panjang gelombang 444 $\mathrm{nm}$, karena hasil yang diperoleh dari beberapa kromatogram menunjukkan karotenoid CPO memiliki penyerapan maksimum pada panjang gelombang tersebut.

Secara kualitatif, pigmen CPO baik fraksi cair maupun padat, tidak berbeda jika dilihat dari puncakpuncak yang dihasilkan pada kromatogram hasil analisis KCKT (Tabel 2). Terlihat bahwa kedua sampel baik fraksi cair maupun padat didominasi oleh $\alpha$ - dan $\beta$-karoten dan teramati jelas dari kromatogram tiga dimensi (Gambar 4). Beberapa pigmen dapat diidentifikasi, baik menggunakan marker maupun pola spektra yang diperkuat dengan literatur.

Penggunaan detektor PDA memberikan beberapa kemudahan. Dengan hanya sekali analisis dapat diperoleh kromatogram pada berbagai panjang gelombang sesuai interval yang dipilih (200-800 nm), sehingga diperoleh pola spektra dari tiap-tiap puncak. Pola spektra ini membantu dalam mengidentifikasi secara kualitatif jenis karotenoid dari tiap puncak tanpa harus menganalisis marker. Jika dibandingkan dengan detektor UV-Tampak konvensional, sekali analisis memerlukan analisis marker sebagai pembanding dan hanya dapat diamati pada satu panjang gelombang. Dapat dibayangkan jika suatu sampel terdiri atas 10 komponen, maka diperlukan 10 marker untuk mengidentifikasinya.

Puncak-puncak yang dihasilkan pada 10 menit pertama tidak terpisah dengan baik. Penggunaan kolom fasa terbalik (reverse-phase) dengan fasa gerak bersifat cenderung polar, memungkinkan komponen-komponen awal tersebut merupakan senyawa-senyawa yang bersifat polar. Metoda tersebut kurang cocok untuk memisahkan komponen-komponen polar, sehingga perlu modifikasi untuk memperoleh pemisahan yang baik, misalnya dengan menggunakan gradien pelarut. 


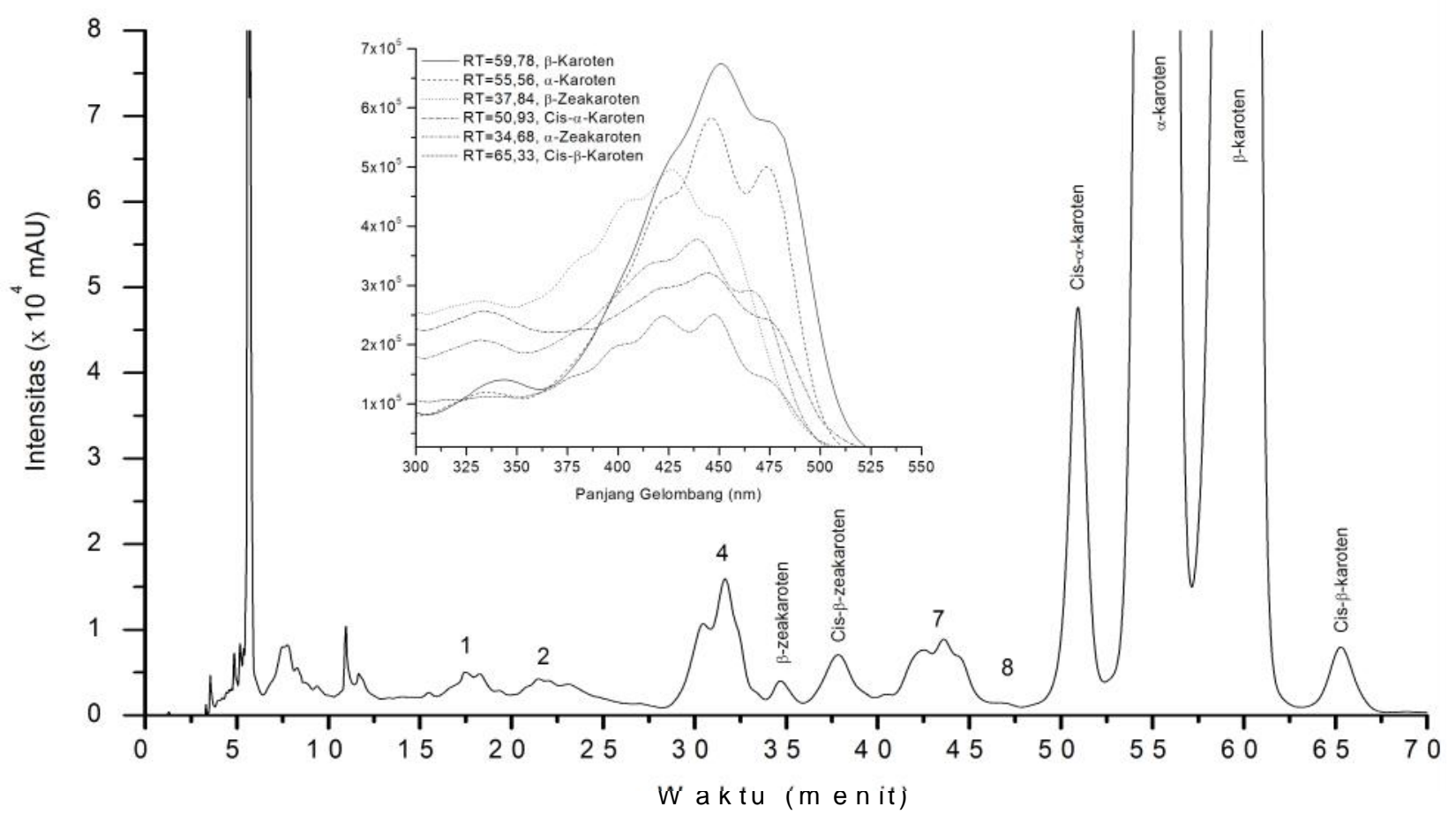

Gambar 2. Kromatogram KCKT fraksi cair dengan deteksi pada panjang gelombang 444nm dan pola spektra dari karotenoid yang dapat diidentifikasi

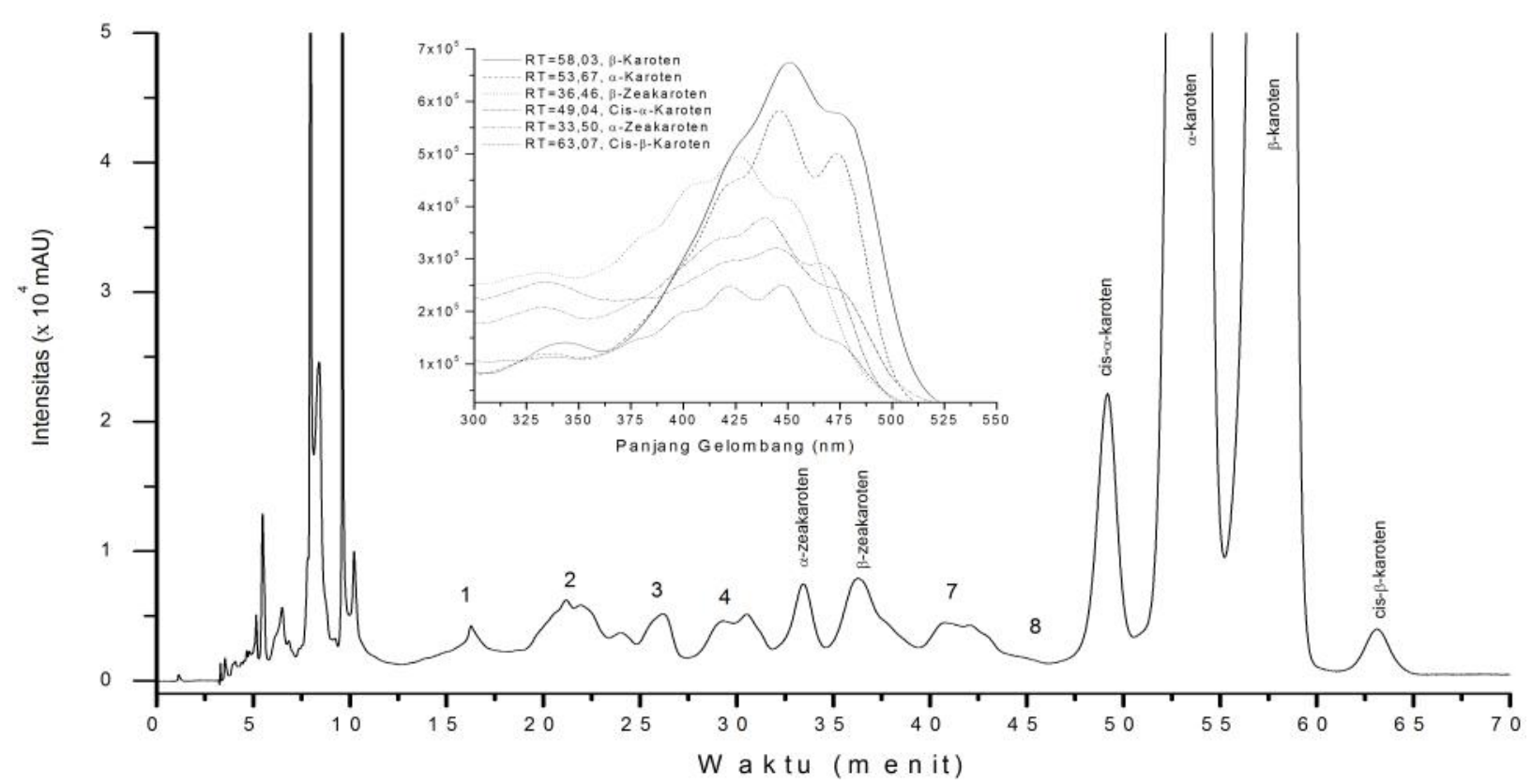

Gambar 3. Kromatogram KCKT fraksi padat CPO dengan deteksi pada panjang gelombang $444 \mathrm{~nm}$ dan pola spektra masing-masing karotenoid

Berdasarkan kromatogram yang dihasilkan tidak semua puncak dapat diidentifikasi. Komponen dengan konsentrasi rendah, pola spektra tidak dapat teramati dengan baik, sehingga masih diperlukan marker sebagai pembanding. Untuk mendapatkan pola spektra dari komponen minor, dapat dilakukan dengan meningkatkan konsentrasi sampel sebelum dianalisis dengan KCKT, dengan konsekuensi tersaturasinya komponen-komponen dominan.
Pola spektra $\alpha$ - dan $\beta$-karoten yang dihasilkan menunjukkan terbentuknya produk degradasi cis-, yang tergambar pada puncak yang muncul di sekitar 143 nm dari puncak tertinggi (Gross 1991). Hal ini terbukti pada pola spektra dari hasil analisis marker $\beta$-karoten, E-Merck No. Kat. 1.02236 (Gambar 5). Produk degradasi cis, tidak muncul pada pola spektra hasil pengukuran dengan spektrofotometer Varian Carry. Tetapi dengan sampel marker yang sama, pola spektra 
Tabel 2. Serapan maksimum masing-masing komponen hasil kromatogram KCKT dengan detektor PDA

\begin{tabular}{|c|c|c|c|c|c|c|c|c|c|c|}
\hline \multirow{3}{*}{$\begin{array}{c}\text { Puncak } \\
1\end{array}$} & \multirow{3}{*}{$\begin{array}{c}\text { Waktu Retensi } \\
\text { (menit) } \\
16,44\end{array}$} & \multirow[t]{3}{*}{ Komponen } & \multicolumn{8}{|c|}{ Absorbansi Maksimum } \\
\hline & & & \multicolumn{4}{|c|}{ Hasil } & \multicolumn{4}{|c|}{ Choo (2000) } \\
\hline & & & 377 & 398 & 421 & & & & & \\
\hline 2 & 22,30 & Belum diketahui & 335 & 405 & 425 & 441 & & & & \\
\hline 5 & 33,50 & $\alpha-$ Zeakaroten & (332) & 402 & 421 & 449 & 400 & 423 & 448 & \\
\hline 6 & 36,46 & $\beta$-Zeakaroten & $(330)$ & 405 & 427 & 452 & 400 & 430 & 449 & \\
\hline 9 & 49,04 & Cis $-\alpha-$ Karoten & 331 & 415 & 441 & 468 & 333 & 415 & 442 & 468 \\
\hline 10 & 53,67 & $\alpha-$ Karoten & (332) & 420 & 446 & 473 & 420 & 445 & 474 & \\
\hline 11 & 58,03 & $\beta$ - Karoten & (337) & 425 & 451 & 476 & 430 & 452 & 477 & \\
\hline 12 & 63,07 & Cis $-\beta-$ Karoten & 331 & 420 & 441 & 475 & 330 & 420 & 440 & 480 \\
\hline 13 & 66,88 & Pitoen ${ }^{*}$ & 276 & 286 & 297 & & 275 & 287 & 297 & \\
\hline Marker & 56,83 & $\beta$ - Karoten & (342) & 426 & 451 & 475 & & & & \\
\hline
\end{tabular}

*Pitoen tidak terlihat pada kromatogram dengan panjang gelombang $444 \mathrm{~nm}$, karena pitoen terdeteksi hanya pada 286 dan 347

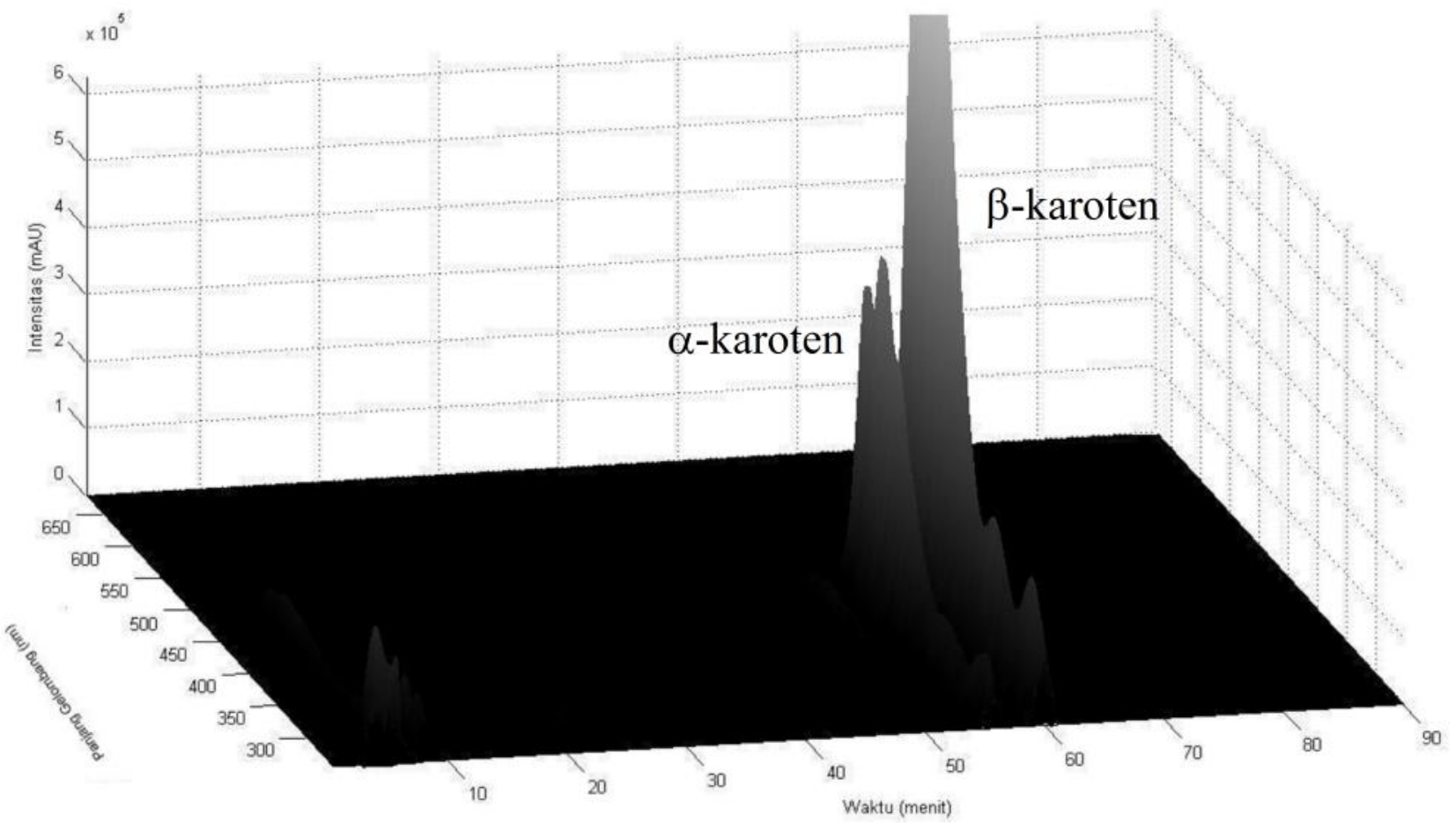

Gambar 4. Kromatogram tiga dimensi KCKT dengan deteksi PDA pada kisaran penyerapan UV-Tampak dari salah satu fraksi sample $\mathrm{CPO}$

produk degradasi muncul pada pengukuran dengan KCKT detektor PDA. Hal tersebut dimungkinkan karena panjangnya waktu analisis, pemilihan pelarut, fasa gerak maupun suhu kolom, seperti yang juga dialami oleh Choo et al, (1994).

Komposisi karotenoid CPO pada kedua fraksi. Penentuan komposisi karotenoid total diharapkan meliputi rentang panjang gelombang ultraviolet dan sinar tampak (200-800 nm). Untuk hal tersebut, software KCKT Shimadzu LC20 belum mampu mengolah data tersebut, sehingga dibuat software pengolah data tersendiri dengan sistem dasar operasi Matlab 6.5.
Piranti lunak (Software) pengolah data dioperasikan, kemudian data numerik tiga dimensi kromatogram yang diperoleh dari instrumen KCKT Shimadzu LC20 dibuka sesuai dengan perintah software. Setelah itu ditentukan jumlah puncak yang diinginkan dan gambar kromatogram akan muncul secara otomatis. Kromatogram tersebut merupakan gabungan dari semua kromatogram pada rentang panjang gelombang sesuai interval yang ditentukan, dalam hal ini 190-800 nm. Komposisi komponen akan ditampilkan dalam bentuk diagram dalam unit persen (\%) sesuai dengan puncak-puncak yang ditentukan. 


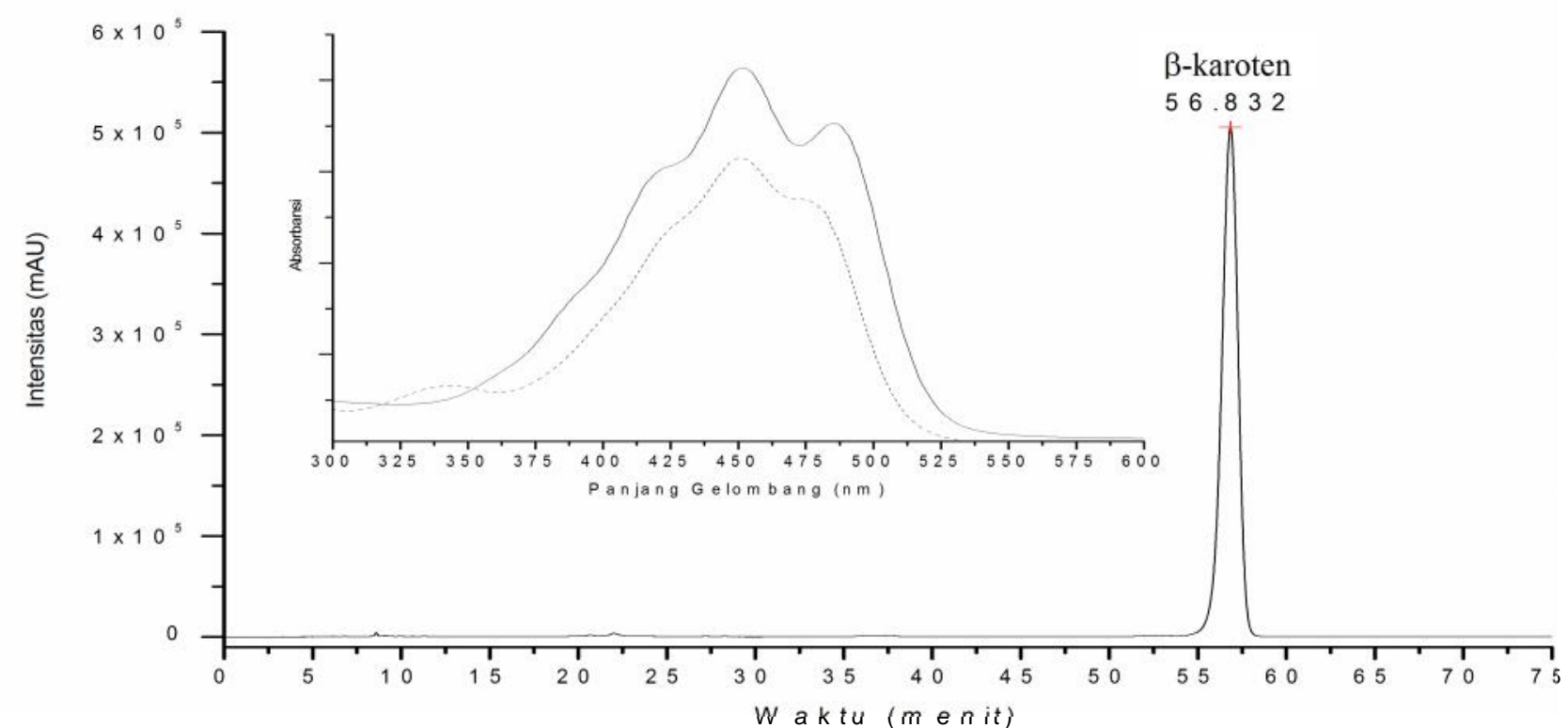

Gambar 5. Kromatogram dan pola spektra marker $\beta$-karoten hasil pengukuran menggunakan Spektrofotometer Varian Carry (\%) dan KCKT dengan detektor PDA (...)

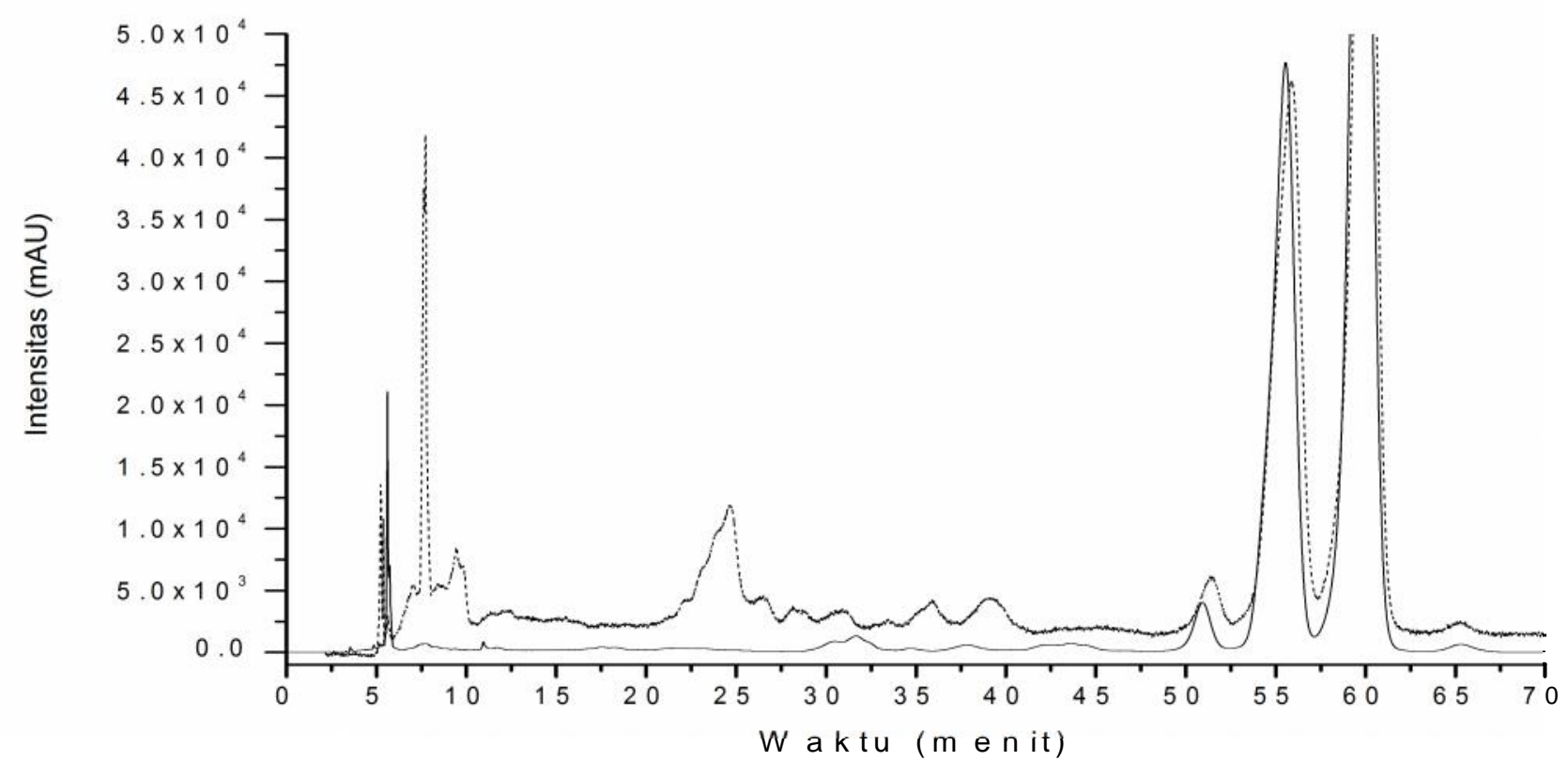

Gambar 6. Kromatogram fraksi cair dengan Saponifikasi $(\rightarrow$ dan metoda langsung $(\cdots)$ Kromatogram dinormalisasi sehingga tinggi puncak-puncak dominan memiliki tinggi yang sama

Pada penelitian ini juga dilakukan analisis komposisi karotenoid dengan metoda langsung tanpa saponifikasi. Saponifikasi merupakan metode untuk memisahkan lemak dan klorofil. Dalam metoda langsung ini, sampel CPO baik dari fraksi padat maupun cair dilarutkan dalam heksan $(1: 100)$. Setelah disaring dengan membran filtrat, sampel langsung diinjeksikan pada KCKT Shimadzu LC-20AB. Metode ini tentu lebih mudah, cepat dan murah karena tidak diperlukan persiapan, ekstrasi dan isolasi karotenoid sebelum dianalisis.
Pada Gambar 6, metoda langsung menghasilkan puncak yang relatif lebih tinggi pada menit ke 0-40 dibandingkan dengan hasil metode saponifikasi. Ini dimungkinkan karena karotenoid terdegradasi selama proses saponifikasi. Beberapa pigmen labil dalam suasana basa, antara lain astaxantin, fukosantin (Gross 1991). Saponifikasi juga dapat merusak golongan santofil. Di alam santofil seringkali ditemukan dalam bentuk ester asam lemak. Ester ini akan rusak pada proses saponifikasi (Britton 1995). Hal yang menarik, 
Tabel 3. Komposisi karotenoid ( $\mu \mathrm{g} / \mathrm{g})$ pada panjang gelombang $200-800 \mathrm{~nm}$ berdasarkan luas area hasil perhitungan Matlab 6.5

\begin{tabular}{|c|c|c|c|c|c|}
\hline \multirow{4}{*}{$\begin{array}{l}\text { Pun- } \\
\text { cak }\end{array}$} & \multirow{4}{*}{ Jenis Karoten } & \multicolumn{4}{|c|}{ Komposisi (\%)* } \\
\hline & & \multicolumn{2}{|c|}{$\begin{array}{c}\text { Metoda } \\
\text { Saponifikasi }\end{array}$} & \multicolumn{2}{|c|}{$\begin{array}{c}\text { Metoda } \\
\text { Langsung }\end{array}$} \\
\hline & & Fraksi & Fraksi & Fraksi & Fraksi \\
\hline & & Cair & Padat & Cair & Padat \\
\hline 1 & Belum diketahui & 0,38 & 2,16 & 0,01 & 0,76 \\
\hline 2 & Belum diketahui & 1,07 & 1,74 & 6,02 & 8,87 \\
\hline 5 & $\alpha-$ Zeakaroten & 2,59 & 1,07 & 0,96 & 0.01 \\
\hline 6 & $\beta$ - Zeakaroten & 0,76 & 1,23 & 1,67 & 1,73 \\
\hline 9 & Cis $-\alpha-$ Karoten & 2,42 & 2,22 & 1,98 & 1,95 \\
\hline 10 & $\alpha-$ Karoten & 29,03 & 25,89 & 28,14 & 30,00 \\
\hline 11 & $\beta-$ Karoten & 60,88 & 60,81 & 59,44 & 56,92 \\
\hline 12 & Cis $-\beta-$ Karoten & 0,67 & 0,69 & 0,53 & 0,27 \\
\hline 13 & Pitoen & 0,13 & 0,15 & $\begin{array}{c}\text { Tdk } \\
\text { terde- } \\
\text { teksi }\end{array}$ & $\begin{array}{c}\text { Tdk } \\
\text { terde- } \\
\text { teksi }\end{array}$ \\
\hline
\end{tabular}

*) Komposisi dilakukan dengan 5 kali ulangan

karotenoid dominan seperti $\alpha$ - dan $\beta$-karoten pada kedua metoda baik langsung maupun dengan metode saponifikasi, memiliki rasio yang relatif sama, sehingga dapat dikatakan bahwa saponifikasi tidak mempengaruhi karotenoid dominan, golongan karotenoid.

Metode langsung bukan tanpa resiko. Kandungan lemak yang tinggi mengganggu kinerja instrumen KCKT terutama kolom. Tekanan pompa KCKT pada metoda langsung, mengalami kenaikan 5-10 bar dari pengukuran biasa. Untuk itu penggunaan guard column dan pencucian kolom setelah pengukuran mutlak harus dilakukan untuk memastikan kolom bersih dari lemak.

\section{KESIMPULAN}

CPO baik dalam fraksi cair maupun padat memiliki kandungan karotenoid dan vitamin A yang tinggi. Kandungan karotenoid total fraksi cair dan padat berturut-turut adalah $536 \pm 13,2 \mu \mathrm{g} / \mathrm{g}$ dan $352 \pm 17,7$ $\mu \mathrm{g} / \mathrm{g}$, sedangkan kandungan vitamin A fraksi cair dan padat 89,4 $\pm 2,2$ RE dan 58,7 $\pm 3,0$ RE. Karotenoid tersebut didominasi oleh $\alpha$ - dan $\beta$-karoten. Dengan metoda saponifikasi diperoleh kandungan $\alpha$ - dan $\beta$ karoten pada fraksi cair berturut-turut $29,03 \%$ dan 60,88 $\%$, sedangkan pada metoda langsung kandungan $\alpha$ dan $\beta$-karoten $28,14 \%$ dan $59,44 \%$. Kandungan $\alpha$ - dan $\beta$-karoten pada fraksi padat metoda saponifikasi berturut-turut $25,89 \%$ dan $60,8 \%$, sedangkan pada metoda langsung kandungan $\alpha$ - dan $\beta$-karoten $30,00 \%$ dan $56,92 \%$.
Analisis komposisi karotenoid menggunakan KCKT dengan detektor PDA memberikan kemudahan dibandingkan dengan detektor UV-tampak. Dalam satu kali analisis detektor PDA memberikan seluruh kromatogram pada rentang panjang gelombang yang diinginkan mulai dari $190 \mathrm{~nm}$ sampai dengan $800 \mathrm{~nm}$ dan dapat menghasilkan kromatogram tiga dimensi (3D). Dari detektor PDA, pola spektra dari tiap komponen dapat diperoleh sehingga memudahkan identifikasi tanpa memerlukan marker.

Hal lain pada sampel CPO baik fraksi cair maupun padat yang larut sempurna dalam pelarut organik (misalnya heksan), analisis karotenoid langsung tanpa ekstraksi dan saponifikasi dimungkinkan untuk dilakukan. Namun ada beberapa hal yang tetap harus diperhatikan terutama dalam menjaga kolom dari lemak dan senyawa lainnya. Tetapi hal ini sebaiknya dihindari jika instrumen KCKT tidak dilengkapi dengan guard column dan pemeliharaan kolom harus diperhatikan.

\section{UCAPAN TERIMA KASIH}

Penulis mengucapkan terima kasih kepada Departemen Pendidikan Nasional yang telah memberikan bantuan program Beasiswa Unggulan, dan Dr. Suryasatria Trihandaru yang telah membantu dalam pembuatan software dengan sistem operasi Matlab 6.5 untuk perhitungan komposisi karotenoid dari data numerik KCKT Shimadzu LC-20 dengan detektor PDA. Terima kasih juga kepada Bpk. Tony Liwang (PT SMART Tbk) dan Lia Kusmita atas dukungannya.

\section{DAFTAR PUSTAKA}

Anonim. 2006. PT. SMART Tbk for company presentation. 1-33 Anonim. 2004. Method Test for Palm Oil Products. MPOB test method Seri 2.1 Bagian 1.

Beecher, G.R. \& Khachik, F. 1984. Evaluation of vitamin A and carotenoid data in foods composition tables. JNCL 73(6).

Bonnie, T.Y.P. \& Choo, Y.M. 2000. Practical guide to establishing palm carotenoids profile by HPLC with three dimensional diode array detector. Palm Oil Development 33: 13-17.

Britton, G., Liaaen-Jensen, S. \& Pfander, H. 1995. Carotenoids Volume 1A: Isolation and Analysis. Berlin: Birkhauser Verlag.

Choo, Y.M. 1994. Palm Oil Carotenoids. The United Nation University Press Food

And Nutrition Bulletin Vol. 15

Choo, Y.M. 1994. Practical Guide to Establishing Palm Carotenoids Profiles by HPLC with Three Dimensional Diode Array Detector. And Nutrition Bulletin Vol 15

Corley, R.H.V. \& Tinker, P.B. 2003. The Palm Oil. Black Well Science.

Foppen F.H. 1971. Table for the identification of carotenoid pigments. Chromatographic Reviews 14:133-298.

Frank A. H. \& Cogdell R. J. 1995. Carotenoids in photosintesis. Photochemistry and Photobiology 63 (3): 257-264. 
Glover J. 1960. The conversion of ${ }^{2}$-carotene into vitamin A. Vitams. Horm. 18: 371-386.

Gross J. 1987. Pigment in Fruits. New York: Academic Press

Gross J. 1991. Pigment in Vegetables: Chlorophylls and Carotenoids. New York: Van Nostrand Reinhold.

Gunstone F. D. 1987. Palm Oil. Critical Report on Applied Chemistry Vol. 15. John Wiley and Sons.

Henderson A. 1986. Barcella odora. Principes. 30: 74-76.

Jeffrey S. W., Mantoura, R. F. C., \& Wright, S. W. 1997. Phytoplankton Pigments in Oceanography; Guidelines to Modern Method. Paris: UNESCO Publishing.

Kusmita L. 2006. Jenis Kandungan dan Aktivitas Antioksidan Karotenoid Provitamin A Limbah Serabut Kelapa Sawit. Tesis. Univ. Kristen Satyawacana.

Lee, C. Y., Simpson, K.L \& Gerber, L. 1989. Vegetables as a major vitamin a source in our diets. Food Life Sci. Bill 126: 1-11

Lila, M. A. 2004. Plant pigments and human health. Davis/Plant Pigments and Their Manipulation. 248-274
Naibaho P. 1998. Teknik Pengolahan Kelapa Sawit. Pusat Penelitian Kelapa Sawit (PPKS) Medan

Nyambaka, Hudson \& Ryley, Janice. 1996. An Isocratic reversed-phase HPLC Separation of the pro-vitamin A carotenoids ( \pm - and ${ }^{2}$-carotene) in dark green vegetables. Food Chemistry 55(1): 63-72.

Paiva. A.R.S. \& Russell R.M. 1999. ${ }^{2}$-carotene and other carotenoids as antioxidant. Journal of The American Nutrition 8(5): 426- 433.

Pangaribuan, Y. \& Aswani, N. 2005. Studi kadar $\beta$-karoten pada minyak kelapa sawit. Jurnal PPKS 13(2)

Sharma, G. K., Semwal, A. D. \& Arya, S. S. 2000. Effect of processing treatments on the carotenoids composition of dehydrated carrots. J. Food Sci. Technology 37(2): 196200.

Tagashira, et al. 2005. In vitro antioxidant activity of some Teucrium species (lamiaceace). Acta. Pharm. 55: 207-214.

Tobing, R. L.1989. Kimia Bahan Alam. Depdikbud Direktorat Jenderal Pendidikan Tinggi. Proyek Pengembangan Lembaga Pendidikan Tenaga Kependidikan. Jakarta. 